\title{
Agronomic performance of modern soybean cultivars in multi-environment trials
}

\author{
Gilvani Matei(1), Giovani Benin ${ }^{(1)}$, Leomar Guilherme Woyann(1), Samuel Cristian Dalló(1), \\ Anderson Simionato Milioli ${ }^{(1)}$ and Andrei Daniel Zdziarski ${ }^{(1)}$
}

(1)Universidade Tecnológica Federal do Paraná, Campus Pato Branco, Via do Conhecimento, Km 01, CEP 85503-390 Pato Branco, PR,
Brazil. E-mail: GMatei@nidera.com.br, benin@utfpr.edu.br, leowoyann@gmail.com, samueldallo@hotmail.com, milioli.utfpr@gmail.com,
dz_andrei@hotmail.com

Abstract - The objective of this work was to evaluate the productive performance, and the adaptability and stability parameters of modern soybean (Glycine max) cultivars in multi-environment trials, as well as to identify the ideal genotypes for eight growing environments in Brazil. A randomized complete block experimental design was carried out, with three replicates, for the evaluation of 46 soybean cultivars in eight environments, in the microregions of adaptation 102, 201, and 202, in the 2014/2015 crop season. A complex genotype $\mathrm{x}$ environment interaction occurred, with changes in the ranking of genotypes among locations. The NA 5909 RG, M6410IPRO, NS 5959 IPRO, NS6823RR, M5917IPRO, NS 6767 RR, and 6563RSF IPRO cultivars showed the highest mean yields. The NA 5909 RG, NS6823RR, M6410IPRO, and NS 5959 IPRO cultivars showed high adaptability and stability and high grain yield, in the evaluated environments, and were ranked next to the ideal genotype for the analyzed environments. There are modern soybean cultivars, which are adapted, stable, and highly productive, for cultivation in the microregions 102, 201, and 202 for soybean crop adaptation in Brazil.

Index terms: Glycine max, adaptability and stability, genotype x environment interaction, GGE biplot, mixed models.

\section{Desempenho agronômico de cultivares modernas de soja em ensaios multiambientes}

Resumo - O objetivo deste trabalho foi avaliar o desempenho produtivo, a adaptabilidade e a estabilidade de cultivares modernas de soja (Glycine max), em ensaios multiambientes, assim como identificar os genótipos ideais para oito ambientes de cultivo no Brasil. Utilizou-se um delineamento experimental de blocos ao acaso, com três repetições, para a avaliação de 46 cultivares em oito ambientes, nas microrregiões de adaptação 102, 201 e 202, na safra 2014/2015. Ocorreu interação genótipo x ambiente complexa, com alterações do ranqueamento de cultivares entre os locais. As cultivares NA 5909 RG, M6410IPRO, NS 5959 IPRO, NS6823RR, M5917IPRO, NS 6767 RR e 6563RSF IPRO apresentaram as maiores médias produtivas. As cultivares NA 5909 RG, NS6823RR, M6410IPRO e NS 5959 IPRO apresentaram elevada adaptabilidade e estabilidade e alta produtividade de grãos, nos ambientes avaliados, e posicionaram-se próximo do que seria considerado ideal para os ambientes analisados. Há cultivares modernas de soja adaptadas, estáveis e com elevada produtividade, para o cultivo nas microrregiões 102, 201 e 202 de adaptação da cultura da soja no Brasil.

Termos para indexação: Glycine max, adaptabilidade e estabilidade, interação genótipo x ambiente, GGE biplot, modelos mistos.

\section{Introduction}

Soybean [Glycine $\max$ (L.) Merr.] is one of the most important crops for the Brazilian economy. Its domestic production reached $96.2 \mathrm{Tg}$ in the 2014/2015 crop season, with a mean yield of approximately $3,000 \mathrm{~kg} \mathrm{ha}^{-1}$ (Conab, 2016).
Genotype $\times$ environment interaction $(\mathrm{GEI})$ is one of the main challenges of soybean breeding programs for both the phases of cultivar selection and recommendation (Branquinho et al., 2014). GEI consists in differentiated genotypic expressions, in different growing environments, and it is responsible for reducing the association between phenotype and 
genotype, reducing genetic progress in breeding programs (Lopes et al., 2012).

Data from multi-environment trials are necessary to assess the presence of GEI, for the evaluation of yield, and genotype adaptability and stability. Adaptability is the ability of the genotype to respond predictably to environmental stimuli, and stability indicates the predictability of performance in different environments. Several methods for adaptability and stability analyses have been described in the literature, which differ according to the statistics - as the analysis of variance, nonparametric regression, multivariate analysis, and the mixed-model analysis -, and according to the parameters used. Methods based on mixed models enable the analysis of genotypes, as that of the random effect analysis; and the multivariate analysis has innovative solutions for the visualization of results.

The mixed-model methods, such as the restricted maximum likelihood/best linear unbiased prediction (REML/BLUP), enable the estimation of variance components and the prediction of genetic values free of environmental effects (Peixouto et al., 2016). The following methods may be used: the harmonic mean of genotypic values (HMGV), in order to infer mean and stability; the relative performance of predicted genotypic values (RPGV), to analyze the genotypic adaptability and the mean yield; and the harmonic mean of the relative performance of predicted genotypic values (HMRPGV), to identify highlyproductive, adapted, and stable genotypes (Gomez et al., 2014; Costa et al., 2015; Spinelli et al., 2015). As mixed models rank the effects of genotypes as random, these methods provide estimates of stability and genotypic adaptability (Resende, 2004).

The use of multivariate statistics, using tools as the GGE biplots, enables summarizing data from a large dataset into a few principal components (PC) (Yan, 2015). Biplots assessing the mean, phenotypic stability, and ideal genotype enable the graphical representation of each cultivar performance, facilitating the selection of superior genotypes (Qin et al., 2015).

The simultaneous use of mixed models based on REML/BLUP and multivariate methods enables the exploration of different adaptability and stability concepts, thereby complementing the collected data, thus increasing the efficacy of the selection of superior genotypes (Andrade et al., 2016).
This study differs from other published ones on the parameters of soybean adaptability, stability, and yield performance because it combines the methods of mixed-models and GGE biplots, in order to assess cultivars widely grown in the Brazilian macroregions of adaptation 1 and 2 .

The objective of this work was to evaluate the yield performance, and the adaptability and stability parameters of modern soybean cultivars, as well as to identify the ideal genotypes for eight growing environments in Brazil, in multi-environment trials.

\section{Materials and Methods}

Forty-six modern soybean cultivars, widely grown in the Brazilian soybean macroregions of adaptation 1 and 2, which were provided for cultivation from 2007 to 2013, were evaluated (Table 1). These cultivars were classified according to their maturity groups (MG) into: early, 4.8 to 5.7 ; medium, 5.8 to 6.2 ; and late, 6.3 to 7.3 .

The experiments were conducted in a randomized complete block design, with three replicates, in eight representative sites of the microregions of adaptation 102, 201, and 202, in the 2014/2015 crop season (Table 2). The sites were selected within microregion 201 and nearby regions with similar sowing season and climatic characteristics. This region has the highest soybean production in Southern Brazil. The experimental units consisted of four $5 \mathrm{~m}$ rows, spaced at $0.5 \mathrm{~m}$ between rows. The sowing density

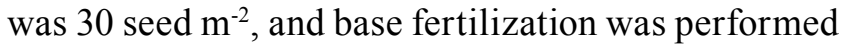
using 7, 70, and $70 \mathrm{~kg} \mathrm{ha}^{-1}$ of $\mathrm{N}, \mathrm{P}_{2} \mathrm{O}_{5}$, and $\mathrm{K}_{2} \mathrm{O}$, respectively. Mechanical sowing and harvesting were carried out. The evaluated trait was grain yield (GY, $\left.\mathrm{kg} \mathrm{ha}^{-1}\right)$, in the two central rows of each plot $\left(5 \mathrm{~m}^{2}\right.$ useful area), with grain moisture corrected to $13 \%$ (wet basis). Crop managements were conducted according to the technical recommendations for soybean cultivation (Oliveira \& Rosa, 2014).

Initially, variance components were evaluated using the REML, and mean components were obtained using the BLUP, with the Selegen statistical package (Resende, 2002). The models 21 (for the analysis of genetic parameters for each site) and 54 (for the combined analysis of sites) were used.

The analysis of variance was also performed to verify the presence of genotype $\times$ environment 
Table 1. Description of 46 soybean cultivars, maturity group, cycle, year of release, technology and releaser.

\begin{tabular}{|c|c|c|c|c|c|c|}
\hline Number & Cultivar & Maturity Group & Cycle & Year of release & Technology & Releaser \\
\hline 1 & BMX Potência RR & 6.7 & Later & 2007 & $\mathrm{RR}$ & GDM Genética \\
\hline 2 & DMario $58 \mathrm{i}$ & 5.5 & Early & 2007 & $\mathrm{RR}$ & GDM Genética \\
\hline 3 & NK 7059 RR & 6.2 & Medium & 2007 & $\mathrm{RR}$ & Syngenta \\
\hline 4 & A $6411 R G$ & 6.4 & Later & 2008 & $\mathrm{RR}$ & Nidera \\
\hline 5 & BMX Ativa RR & 5.6 & Early & 2008 & RR & GDM Genética \\
\hline 6 & BMX Energia RR & 5.3 & Early & 2008 & $\mathrm{RR}$ & GDM Genética \\
\hline 7 & NA 5909 RG & 5.9 & Medium & 2008 & $\mathrm{RR}$ & Nidera \\
\hline 8 & NS 4823 & 4.8 & Early & 2008 & $\mathrm{RR}$ & Nidera \\
\hline 9 & BMX Turbo RR & 5.8 & Medium & 2009 & $\mathrm{RR}$ & GDM Genética \\
\hline 10 & NS 5858 & 5.8 & Medium & 2010 & $\mathrm{RR}$ & Nidera \\
\hline 11 & NS 6262 & 6.2 & Medium & 2010 & $\mathrm{RR}$ & Nidera \\
\hline 12 & SYN1059 RR & 5.9 & Medium & 2010 & $\mathrm{RR}$ & Syngenta \\
\hline 13 & NS 6767 RR & 6.7 & Later & 2011 & $\mathrm{RR}$ & Nidera \\
\hline 14 & TMG 7262RR & 6.2 & Medium & 2011 & $\mathrm{RR}$ & TMG \\
\hline 15 & NS 4901 & 4.9 & Early & 2012 & $\mathrm{RR}$ & Nidera \\
\hline 16 & NS 5258 & 5.2 & Early & 2012 & $\mathrm{RR}$ & Nidera \\
\hline 17 & NS 5290 & 5.2 & Early & 2012 & $\mathrm{RR}$ & Nidera \\
\hline 18 & NS 5401 RR & 5.4 & Early & 2012 & $\mathrm{RR}$ & Nidera \\
\hline 19 & NS 6209 & 6.2 & Medium & 2012 & $\mathrm{RR}$ & Nidera \\
\hline 20 & NS6121RR & 6.1 & Medium & 2013 & $\mathrm{RR}$ & Nidera \\
\hline 21 & NS6823RR & 6.8 & Later & 2013 & $\mathrm{RR}$ & Nidera \\
\hline 22 & M6210IPRO & 6.2 & Medium & 2011 & IPRO & Monsoy \\
\hline 23 & M6410IPRO & 6.4 & Later & 2011 & IPRO & Monsoy \\
\hline 24 & 5958RSF IPRO & 5.8 & Medium & 2012 & IPRO & GDM Genética \\
\hline 25 & 6458RSF IPRO & 6 & Medium & 2012 & IPRO & GDM Genética \\
\hline 26 & 6563RSF IPRO & 6.3 & Later & 2012 & IPRO & GDM Genética \\
\hline 27 & AS 3570IPRO & 5.7 & Early & 2012 & IPRO & Monsoy \\
\hline 28 & AS 3610IPRO & 6.1 & Medium & 2012 & IPRO & Monsoy \\
\hline 29 & M5917IPRO & 5.9 & Medium & 2012 & IPRO & Monsoy \\
\hline 30 & NS 5000 IPRO & 5 & Early & 2012 & IPRO & Nidera \\
\hline 31 & NS 5106 IPRO & 5.1 & Early & 2012 & IPRO & Nidera \\
\hline 32 & NS 5151 IPRO & 5.1 & Early & 2012 & IPRO & Nidera \\
\hline 33 & NS 5445 IPRO & 5.4 & Early & 2012 & IPRO & Nidera \\
\hline 34 & NS 5959 IPRO & 5.9 & Medium & 2012 & IPRO & Nidera \\
\hline 35 & NS 6909 IPRO & 6.9 & Later & 2012 & IPRO & Nidera \\
\hline 36 & NS 7000 IPRO & 7 & Later & 2012 & IPRO & Nidera \\
\hline 37 & NS 7209 IPRO & 7.2 & Later & 2012 & IPRO & Nidera \\
\hline 38 & NS 7237 IPRO & 7.2 & Later & 2012 & IPRO & Nidera \\
\hline 39 & NS 7300 IPRO & 7.3 & Later & 2012 & IPRO & Nidera \\
\hline 40 & NS 7338 IPRO & 7.3 & Later & 2012 & IPRO & Nidera \\
\hline 41 & NS 5727 IPRO & 5.7 & Early & 2013 & IPRO & Nidera \\
\hline 42 & NS 6006 IPRO & 6 & Medium & 2013 & IPRO & Nidera \\
\hline 43 & NS6060IPRO & 6 & Medium & 2013 & IPRO & Nidera \\
\hline 44 & NS6700IPRO & 6.7 & Later & 2013 & IPRO & Nidera \\
\hline 45 & NS6906IPRO & 6.9 & Later & 2013 & IPRO & Nidera \\
\hline 46 & TMG2158IPRO & 5.8 & Medium & 2013 & IPRO & TMG \\
\hline
\end{tabular}


interactions. Subsequently, a cluster analysis of means was performed using the Scott-Knott test, at $5 \%$ probability, and the Genes statistical software package (Cruz, 2013). Yield means of each genotype, at each site, and for the set of sites, were also indicated.

Data on genetic effects (g), predicted genotypic values $(\mathrm{u}+\mathrm{g})$, and the gain of each genotype with the removal of the environmental component were also determined in the analysis, using the model 54 of the Selegen software package (Resende, 2002).

The new genotype mean was obtained with this gain, and ranking was performed using this new value. Furthermore, the mean genotypic value $(\mathrm{u}+\mathrm{g}+\mathrm{gem})$ was obtained in the various environments; this indicated the average interaction with all evaluated environments (Resende, 2002). Using this model, the following parameters could also be obtained: genotypic stability using HMGV; genotypic adaptability and yield performance, using RPGV multiplied by the overall mean (OM) of all sites $\left(\mathrm{RPGV}^{*} \mathrm{OM}\right)$; and the genotypic stability and adaptability, and crop yiel performance, using HMRPGV*OM.

Stability was also assessed using the GGEbiplot software (Yan, 2001), which analyzes the stability of genotypes associated with their mean yield. For this purpose, the following parameters were used: data transformation (Transform $=0$, without transformation), data scale (Scaling $=0$, without

Table 2. Identification of test locations in the states of Paraná (PR) and São Paulo (SP), Brazil, used to evaluate 46 soybean cultivars, in the $2014 / 2015$ crop season $^{(1)}$.

\begin{tabular}{lcccccc}
\hline $\begin{array}{l}\text { Municipality, } \\
\text { state }^{(1)}\end{array}$ & $\begin{array}{c}\text { Macro-- } \\
\text { region }^{(2)}\end{array}$ & $\begin{array}{c}\text { Micro- } \\
\text { region }^{(2)}\end{array}$ & $\begin{array}{c}\text { Lati- } \\
\text { tude }\end{array}$ & $\begin{array}{c}\text { Longi- } \\
\text { tude }\end{array}$ & $\begin{array}{c}\text { Altitude Climate } \\
(\mathrm{m})\end{array}$ & \\
\hline Cambé, PR & 2 & 201 & $23^{\circ} 16^{\prime} \mathrm{S}$ & $51^{\circ} 16^{\prime} \mathrm{W}$ & 520 & $\mathrm{Cfa}$ \\
CM, SP & 2 & 201 & $22^{\circ} 44^{\prime} \mathrm{S}$ & $50^{\circ} 23^{\prime} \mathrm{W}$ & 440 & $\mathrm{Cwa}$ \\
Corbélia, PR & 2 & 201 & $24^{\circ} 47^{\prime} \mathrm{S}$ & $53^{\circ} 18^{\prime} \mathrm{W}$ & 650 & $\mathrm{Cfa}$ \\
Mamborê, PR & 2 & 201 & $2^{\circ} 19^{\prime} \mathrm{S}$ & $52^{\circ} 31^{\prime} \mathrm{W}$ & 715 & $\mathrm{Cfa}$ \\
Palotina, PR & 2 & 201 & $24^{\circ} 17^{\prime} \mathrm{S}$ & $53^{\circ} 50^{\prime} \mathrm{W}$ & 330 & $\mathrm{Cfa}$ \\
Realeza, PR & 1 & 102 & $2^{\circ} 46^{\prime} \mathrm{S}$ & $53^{\circ} 31^{\prime} \mathrm{W}$ & 520 & $\mathrm{Cfa}$ \\
SJI, PR & 2 & 202 & $2^{\circ} 25^{\prime} \mathrm{S}$ & $52^{\circ} 17^{\prime} \mathrm{W}$ & 560 & $\mathrm{Cfa}$ \\
SMI, PR & 2 & 201 & $25^{\circ} 20^{\prime} \mathrm{S}$ & $54^{\circ} 14^{\prime} \mathrm{W}$ & 290 & $\mathrm{Cfa}$ \\
\hline
\end{tabular}

${ }^{(1)} \mathrm{CM}$, Cândido Mota municipality; SJI, São Jorge do Ivaí municipality; SMI, São Miguel do Iguaçu municipality. ${ }^{(2)}$ Macroregion is determined by latitude (photoperiod/temperature) and rainfall; and microregions, within a same macroregion, differ by temperature (altitude) and soil type (Kaster \& Farias, 2012). ${ }^{(3)}$ The climate refers to Köppen climate classification. scale), data centering (Data centering $=2$, genotype plus genotype by environment interaction $(\mathrm{G}+\mathrm{GEI})$, and singular-value partitioning ( $\mathrm{SVP}=1$, focus on genotype). The concept of ideal genotype was also evaluated with the GGEbiplot software (Yan, 2001), using the same parameters as those for the mean and stability analyses.

\section{Results and Discussion}

In the combined analysis, the estimation of heritability in the broad sense $\left(\mathrm{h}_{\mathrm{g}}^{2}\right)$ for grain yield (GY) was $0.37( \pm 0.05)$, which is lower than the estimate usually obtained for agronomic characters controlled by a few genes, but within the expected range for characters controlled by many genes of small effects, as GY (Table 3). Low values of $\mathrm{h}_{\mathrm{g}}{ }_{\mathrm{g}}$ indicate the need for a breakdown in the GEI because they result from changes in the behavior of the genotypes in the studied sites (Rosado et al., 2012). Interaction analysis allows the maximization of selection gains, when testing homozygous clones or lines. Similar results were obtained by other authors (Pinheiro et al., 2013; Rocha et al., 2015; Andrade et al., 2016), who also found low-heritability estimates for soybean GY. The value of interaction variance $\left(\mathrm{V}_{\mathrm{G} \times \mathrm{A}}\right)$, when higher than the genotypic variance $\left(\mathrm{V}_{\mathrm{G}}\right)$, also contributes to the low values of the $\mathrm{h}_{\mathrm{g}}^{2}$ estimates. In the individual analysis of the sites, $\mathrm{h}_{\mathrm{g}}{ }_{\mathrm{g}}$ was higher, ranging from 0.60 to 0.92 , which indicates that a large part of the phenotypic variance $\left(\mathrm{V}_{\mathrm{F}}\right)$ resulted from $\mathrm{V}_{\mathrm{G}}$. The value of standard deviation, at each site, was higher than that verified for the set of study environments, ranging from 0.19 to 0.23 . However, these standard deviation values are within acceptable limits, which indicates that the predictions are reliable for use in breeding (Resende, 2004).

The genotypic coefficient of variation (CVgi\%) was $11.73 \%$ in the combined analysis of sites, and ranged from $10.49 \%$, in the municipality of Cambé, in Paraná state, to $23.41 \%$, in the municipality of Cândido Mota, in São Paulo state. Sites with higher CVgi\% values favor the discrimination of genotypes, that is, they promote a wider performance range, favoring selection. The residual coefficient of variation $(\mathrm{CVe} \%)$ ranged from $4.95 \%$ in the municipality of Realeza, to $9.19 \%$ in the municipality of Palotina, both in the state of Paraná. These values are considered low and indicate good experimental 


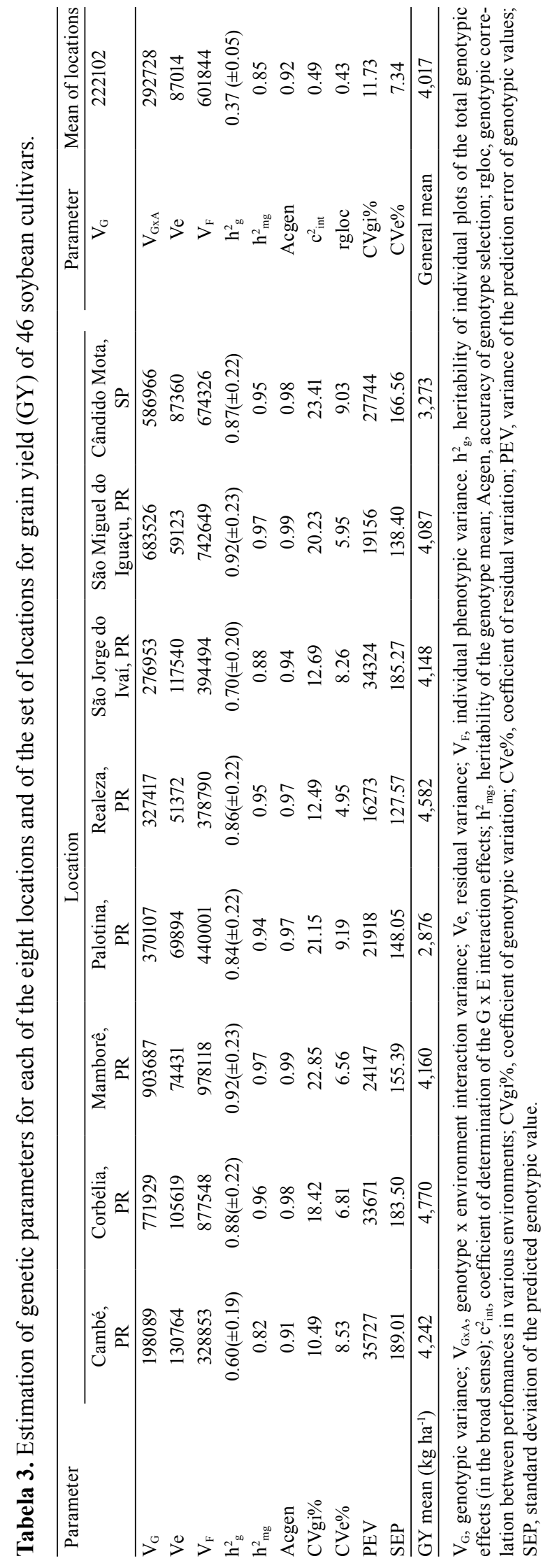

precision. Genotypic selection accuracy (Acgen) for the set of sites was 0.92, and ranged from 0.91 in Cambé to 0.99 in Mamborê and in São Miguel do Iguaçu, all municipalities in the state of Paraná, indicating the high experimental precision obtained in all study environments. This parameter involves correlating the true genotypic value of the genetic treatment with the genotypic value estimated, or predicted, from experimental data. These values may be classified within the very high-accuracy class (Acgen > 0.90) (Resende \& Duarte, 2007).

The genotypic correlation between performances in the various environments (rgloc) was 0.43 . This value indicates the occurrence of a complex interaction between genotypes and test sites, which entails different genotypic responses at the different sites where they are evaluated, changing the ranking between sites (Costa et al., 2015). Furthermore, this also indicates that sites in the same soybean microregion of adaptation show considerable differences for cultivar performance. This is the case with microregion 201 (macroregion 2). The sites Realeza, in microregion 102 (macroregion 1), and São Jorge do Ivaí, in microregion 202 (macroregion 2), both in the state of Paraná, showed crop yield performance similar to that assessed in microregion 201. Besides, large variations of performance were observed even in study sites with latitude variation smaller than $3^{\circ}$. Therefore, breeders should conduct several comparative trials of cultivars within the same subregion, in order to identify the specificity of each site where they intend to plant their cultivars.

The mean GY of the trials was $4,017 \mathrm{~kg} \mathrm{ha}^{-1}$ (Table 4), which is higher than the mean of the MidwesternSouthern region of Brazil (3,016 kg ha-1), and higher than those of regions in Paraná $\left(3,294 \mathrm{~kg} \mathrm{ha}^{-1}\right)$ and São Paulo (2,970 $\left.\mathrm{kg} \mathrm{ha}^{-1}\right)$ states, according to Companhia Nacional de Abastecimento (Conab, 2016). The mean yields obtained in the trials for each site ranged from $2,876 \mathrm{~kg} \mathrm{ha}^{-1}$, in Palotina, to 4,770 $\mathrm{kg} \mathrm{ha}^{-1}$ in Corbélia, both in the state of Paraná.

In the set of the evaluated environments, the highest yields were observed for NA 5909 RG, M6410IPRO, NS 5959 IPRO, NS6823RR, M5917IPRO, NS $6767 \mathrm{RR}$, and 6563RSF IPRO cultivars with 4,851, 4,705, 4,670, 4,644, 4,590, 4,589 , and 4,578 $\mathrm{kg} \mathrm{ha}^{-1} \mathrm{GY}$, respectively. The highest absolute production $\left(6,265 \mathrm{~kg} \mathrm{ha}^{-1}\right)$ was obtained 
Table 4. Grain yield $\left(\mathrm{kg} \mathrm{ha}^{-1}\right)$ of soybean cultivars, grouping means by the Scott-Knott test, and mean of cultivars in eight sites GY ( $\bar{X} \mathrm{G})$, mean of each location ( $\overline{\mathrm{X}} \mathrm{L})$, and mean of 46 soybean cultivars classified according to their cycle, in each site, in the 2014/2015 crop season.

\begin{tabular}{|c|c|c|c|c|c|c|c|c|c|}
\hline \multirow[t]{2}{*}{ Cultivar } & \multicolumn{9}{|c|}{ Locations } \\
\hline & Cambé, PR & Corbélia, PR & Mamborê, PR & Palotina, PR & Realeza, PR & $\begin{array}{l}\text { São Jorge do } \\
\text { Ivaí, PR }\end{array}$ & $\begin{array}{l}\text { São Miguel do } \\
\text { Iguaçu, PR }\end{array}$ & $\begin{array}{l}\text { ândido Mota, } \\
\text { SP }\end{array}$ & $\overline{\mathrm{X}} \mathrm{G}$ \\
\hline BMX Potência RR & $4151 \mathrm{cB}$ & $6186 \mathrm{aA}$ & $4453 \mathrm{bB}$ & $3072 \mathrm{cD}$ & $4348 \mathrm{cB}$ & $4706 \mathrm{bB}$ & $3656 \mathrm{dC}$ & $3859 \mathrm{bC}$ & $4304 c$ \\
\hline DMario $58 \mathrm{i}$ & $4241 \mathrm{cB}$ & $4373 \mathrm{~dB}$ & $4804 \mathrm{bA}$ & $2325 \mathrm{eC}$ & $4623 \mathrm{bA}$ & $3982 \mathrm{cB}$ & $4580 \mathrm{bA}$ & $2602 \mathrm{dC}$ & $3941 d$ \\
\hline NK 7059 RR & $4020 \mathrm{cC}$ & $5813 \mathrm{bA}$ & $3957 \mathrm{cC}$ & $3579 \mathrm{bD}$ & $4461 \mathrm{bC}$ & $3955 \mathrm{cC}$ & $5277 \mathrm{aB}$ & $3364 \mathrm{cD}$ & $4303 c$ \\
\hline A $6411 R G$ & $3495 \mathrm{~dB}$ & $4105 \mathrm{eA}$ & $1174 \mathrm{eD}$ & $2307 \mathrm{eC}$ & $3997 \mathrm{cA}$ & $2840 \mathrm{eC}$ & $2286 \mathrm{fC}$ & $2601 \mathrm{dC}$ & $2851 \mathrm{~h}$ \\
\hline BMX Ativa RR & $2770 \mathrm{eB}$ & $3030 \mathrm{fA}$ & $972 \mathrm{eD}$ & $1743 \mathrm{eC}$ & $3308 \mathrm{dA}$ & $2525 \mathrm{eB}$ & $2269 \mathrm{fB}$ & $1653 \mathrm{fC}$ & $2284 \mathrm{i}$ \\
\hline BMX Energia RR & $3624 \mathrm{~dB}$ & $4445 \mathrm{dA}$ & $4850 \mathrm{bA}$ & $2817 \mathrm{dC}$ & $4953 \mathrm{bA}$ & $4088 \mathrm{cB}$ & $3580 \mathrm{~dB}$ & $3857 \mathrm{bB}$ & $4027 d$ \\
\hline NA 5909 RG & $4614 \mathrm{bB}$ & $5557 \mathrm{bA}$ & $5373 \mathrm{aA}$ & $3240 \mathrm{cC}$ & $5343 \mathrm{aA}$ & $4808 \mathrm{bB}$ & $5283 \mathrm{aA}$ & $4588 \mathrm{aB}$ & $4851 \mathrm{a}$ \\
\hline NS 4823 & $3816 \mathrm{cB}$ & $3129 \mathrm{fC}$ & $3771 \mathrm{cB}$ & $2251 \mathrm{eD}$ & $5086 \mathrm{aA}$ & $3635 \mathrm{~dB}$ & $2836 \mathrm{eC}$ & $2463 \mathrm{dD}$ & $3373 \mathrm{~g}$ \\
\hline BMX Turbo RR & $4495 b B$ & $5108 \mathrm{cB}$ & $5577 \mathrm{aA}$ & $2445 \mathrm{eE}$ & $5000 \mathrm{bB}$ & $3928 \mathrm{cC}$ & $4824 \mathrm{bB}$ & $3202 \mathrm{cD}$ & $4322 c$ \\
\hline NS 5858 & $3947 \mathrm{cB}$ & $3548 \mathrm{fB}$ & $3897 \mathrm{cB}$ & $2242 \mathrm{eC}$ & $4619 \mathrm{bA}$ & $4301 \mathrm{cA}$ & $4278 \mathrm{cA}$ & $3437 \mathrm{cB}$ & $3784 \mathrm{e}$ \\
\hline NS 6262 & $4156 \mathrm{cB}$ & $3938 \mathrm{eB}$ & $4664 \mathrm{bA}$ & $2230 \mathrm{eD}$ & $4980 \mathrm{bA}$ & $4195 \mathrm{cB}$ & $3963 \mathrm{cB}$ & $2726 \mathrm{dC}$ & $3856 \mathrm{e}$ \\
\hline SYN1059 RR & $5099 \mathrm{aA}$ & $4810 \mathrm{cA}$ & $4475 b B$ & $2586 \mathrm{dD}$ & $4749 \mathrm{bA}$ & $4320 \mathrm{cB}$ & $4278 \mathrm{cB}$ & $3605 \mathrm{cC}$ & $4240 c$ \\
\hline NS 6767 RR & $4999 \mathrm{aB}$ & $5886 \mathrm{bA}$ & $4686 \mathrm{bB}$ & $3673 \mathrm{bD}$ & $4104 \mathrm{cD}$ & $4447 \mathrm{cC}$ & 4909bB & 4011aD & $4589 a$ \\
\hline TMG 7262RR & $4441 \mathrm{bB}$ & $5123 \mathrm{cA}$ & $4800 \mathrm{bB}$ & $2158 \mathrm{eC}$ & $5315 \mathrm{aA}$ & $4634 \mathrm{bB}$ & $4288 \mathrm{cB}$ & $2502 \mathrm{dC}$ & $4158 \mathrm{c}$ \\
\hline NS 4901 & $3911 \mathrm{cB}$ & $4182 \mathrm{eB}$ & $3915 \mathrm{cB}$ & $2255 \mathrm{eD}$ & $5090 \mathrm{aA}$ & $4067 \mathrm{cB}$ & $3943 \mathrm{cB}$ & $2832 \mathrm{dC}$ & $3774 \mathrm{e}$ \\
\hline NS 5258 & $4299 \mathrm{bB}$ & $4052 \mathrm{eB}$ & $4035 \mathrm{cB}$ & $2175 \mathrm{eC}$ & $4678 \mathrm{bA}$ & $4670 \mathrm{bA}$ & $4181 \mathrm{cB}$ & $3677 \mathrm{bB}$ & $3971 d$ \\
\hline NS 5290 & $4446 \mathrm{bA}$ & $4228 \mathrm{eA}$ & $4478 \mathrm{bA}$ & $2424 \mathrm{eB}$ & $4586 \mathrm{bA}$ & $4441 \mathrm{cA}$ & $4109 \mathrm{cA}$ & $2317 \mathrm{eB}$ & $3879 \mathrm{e}$ \\
\hline NS 5401 RR & $4093 \mathrm{cA}$ & $3161 \mathrm{fB}$ & $4008 \mathrm{cA}$ & $2474 d \mathrm{dC}$ & $4083 \mathrm{cA}$ & $4081 \mathrm{cA}$ & $4033 \mathrm{cA}$ & $2638 \mathrm{dC}$ & $3571 \mathrm{f}$ \\
\hline NS 6209 & $4199 \mathrm{cB}$ & $5167 \mathrm{cA}$ & $5253 \mathrm{aA}$ & $3122 \mathrm{cC}$ & $3984 \mathrm{cB}$ & $3969 \mathrm{cB}$ & $3607 \mathrm{~dB}$ & $3767 \mathrm{bB}$ & $4134 c$ \\
\hline NS6121RR & $3906 \mathrm{cB}$ & $5345 \mathrm{cA}$ & $3958 \mathrm{cB}$ & $2886 \mathrm{dC}$ & $4247 \mathrm{cB}$ & $4189 \mathrm{cB}$ & $3186 \mathrm{eC}$ & $2976 \mathrm{dC}$ & $3836 \mathrm{e}$ \\
\hline NS6823RR & $4586 \mathrm{bB}$ & $6097 \mathrm{aA}$ & $4277 \mathrm{cC}$ & $3923 b C$ & $4699 \mathrm{bB}$ & $4675 b B$ & $4458 \mathrm{cB}$ & $4437 \mathrm{aB}$ & $4644 a$ \\
\hline M6210IPRO & $4328 \mathrm{bC}$ & $5605 \mathrm{bA}$ & $4257 \mathrm{cC}$ & $3777 b C$ & $4117 \mathrm{cC}$ & $4794 \mathrm{bB}$ & $4705 \mathrm{bB}$ & $3889 \mathrm{bC}$ & $4434 b$ \\
\hline M6410IPRO & $4613 \mathrm{bB}$ & $5711 \mathrm{bA}$ & $4184 \mathrm{cC}$ & $2920 \mathrm{dD}$ & $4815 \mathrm{bB}$ & $5453 \mathrm{aA}$ & $5296 \mathrm{aA}$ & $4645 \mathrm{aB}$ & $4705 \mathrm{a}$ \\
\hline 5958RSF IPRO & $4686 \mathrm{bB}$ & $5402 \mathrm{cA}$ & $4657 \mathrm{bB}$ & $3107 \mathrm{cD}$ & $4188 \mathrm{cC}$ & $3947 \mathrm{cC}$ & $4951 \mathrm{bB}$ & $3499 \mathrm{cD}$ & $4305 c$ \\
\hline 6458RSF IPRO & $4056 \mathrm{cC}$ & $4753 \mathrm{~dB}$ & $4668 \mathrm{bB}$ & $3103 \mathrm{cD}$ & $5130 \mathrm{aA}$ & $4373 \mathrm{cB}$ & $4158 \mathrm{cC}$ & $3905 \mathrm{bC}$ & $4268 c$ \\
\hline 6563RSF IPRO & $5342 \mathrm{aA}$ & $5539 \mathrm{bA}$ & $4970 \mathrm{bB}$ & $3253 \mathrm{cD}$ & $4763 \mathrm{bB}$ & $4029 \mathrm{cC}$ & $4373 \mathrm{cC}$ & $4358 \mathrm{aC}$ & $4578 \mathrm{a}$ \\
\hline AS 3570IPRO & $4200 \mathrm{cA}$ & $3874 \mathrm{eA}$ & $4063 \mathrm{cA}$ & $2243 \mathrm{eC}$ & $3834 \mathrm{cA}$ & $4140 \mathrm{cA}$ & $3084 \mathrm{eB}$ & $3526 \mathrm{cA}$ & $3621 \mathrm{f}$ \\
\hline AS 3610IPRO & $4329 \mathrm{bB}$ & $5175 \mathrm{cA}$ & $4625 \mathrm{bA}$ & $3303 \mathrm{cC}$ & $4776 \mathrm{bA}$ & $4068 \mathrm{cB}$ & $4870 \mathrm{bA}$ & $4149 \mathrm{aB}$ & $4412 b$ \\
\hline M5917IPRO & $4215 \mathrm{cC}$ & $5430 \mathrm{cA}$ & $4793 b B$ & $3368 \mathrm{cD}$ & $4797 b B$ & $4864 \mathrm{bB}$ & $4870 \mathrm{bB}$ & $4379 \mathrm{aC}$ & $4590 \mathrm{a}$ \\
\hline NS 5000 IPRO & $4216 \mathrm{cB}$ & $3360 \mathrm{fC}$ & $3853 \mathrm{cC}$ & $2785 \mathrm{dD}$ & $4861 \mathrm{bA}$ & $3762 \mathrm{dC}$ & $3637 \mathrm{dC}$ & $2217 \mathrm{eE}$ & $3586 \mathrm{f}$ \\
\hline NS 5106 IPRO & $4131 \mathrm{cC}$ & $4051 \mathrm{eC}$ & $3961 \mathrm{cC}$ & $2567 \mathrm{dD}$ & $5416 \mathrm{aA}$ & $4807 \mathrm{bB}$ & $4370 \mathrm{cC}$ & $2436 \mathrm{dD}$ & $3967 d$ \\
\hline NS 5151 IPRO & $4043 \mathrm{cB}$ & $4238 \mathrm{eB}$ & $3879 \mathrm{cB}$ & $2656 \mathrm{dD}$ & $5443 \mathrm{aA}$ & $4093 \mathrm{cB}$ & $3805 \mathrm{cB}$ & $3259 \mathrm{cC}$ & $3927 d$ \\
\hline NS 5445 IPRO & $3328 \mathrm{dC}$ & $4004 \mathrm{eB}$ & $4355 \mathrm{cB}$ & $2125 \mathrm{eD}$ & $5056 \mathrm{aA}$ & $3776 \mathrm{~dB}$ & $3172 \mathrm{eC}$ & $2602 \mathrm{dD}$ & $3552 \mathrm{f}$ \\
\hline NS 5959 IPRO & $4765 \mathrm{bC}$ & $5120 \mathrm{cB}$ & $5532 \mathrm{aA}$ & $2725 \mathrm{dE}$ & $5668 \mathrm{aA}$ & $4490 \mathrm{bC}$ & $5124 \mathrm{aB}$ & 3936bD & $4670 \mathrm{a}$ \\
\hline NS 6909 IPRO & $4579 \mathrm{bA}$ & $4654 \mathrm{dA}$ & $4600 \mathrm{bA}$ & $2521 \mathrm{dC}$ & $4665 \mathrm{bA}$ & $4617 \mathrm{bA}$ & $3796 \mathrm{cB}$ & $2122 \mathrm{eC}$ & $3944 d$ \\
\hline NS 7000 IPRO & $4360 \mathrm{bC}$ & $5730 \mathrm{bA}$ & $3411 d D$ & $3866 \mathrm{bD}$ & $4527 \mathrm{bC}$ & $4923 b B$ & $4151 \mathrm{cC}$ & $4152 \mathrm{aC}$ & $4390 \mathrm{~b}$ \\
\hline NS 7209 IPRO & $4178 \mathrm{cB}$ & $6080 \mathrm{aA}$ & $3026 \mathrm{dD}$ & $4494 \mathrm{aB}$ & $3489 \mathrm{dC}$ & $4320 \mathrm{cB}$ & $4613 b B$ & $3792 \mathrm{bC}$ & $4249 c$ \\
\hline NS 7237 IPRO & $4077 \mathrm{cB}$ & $4895 \mathrm{cA}$ & $3663 \mathrm{cC}$ & $3437 \mathrm{cC}$ & $3399 \mathrm{dC}$ & $4326 \mathrm{cB}$ & $2281 \mathrm{fD}$ & $3019 \mathrm{dC}$ & $3637 f$ \\
\hline NS 7300 IPRO & $4114 \mathrm{cC}$ & $6087 \mathrm{aA}$ & $3975 \mathrm{cC}$ & $3340 \mathrm{cD}$ & 3091dD & $3592 \mathrm{dD}$ & $4852 \mathrm{bB}$ & $3366 \mathrm{cD}$ & $4052 d$ \\
\hline NS 7338 IPRO & $4098 \mathrm{cB}$ & $4628 \mathrm{dA}$ & $3729 \mathrm{cC}$ & $3647 b C$ & $3936 \mathrm{cC}$ & $3629 \mathrm{dC}$ & $4177 \mathrm{cB}$ & $2712 \mathrm{dD}$ & $3819 \mathrm{e}$ \\
\hline NS 5727 IPRO & $4722 \mathrm{bA}$ & $3885 \mathrm{eB}$ & $4274 \mathrm{cB}$ & $2678 \mathrm{dD}$ & $5182 \mathrm{aA}$ & $3062 \mathrm{eC}$ & $3178 \mathrm{eC}$ & $2539 \mathrm{dD}$ & $3690 \mathrm{f}$ \\
\hline NS 6006 IPRO & $4643 \mathrm{bA}$ & $4420 \mathrm{~dB}$ & $5103 \mathrm{aA}$ & $2754 \mathrm{dC}$ & $4870 \mathrm{bA}$ & $3961 \mathrm{cB}$ & $4691 \mathrm{bA}$ & $2505 \mathrm{dC}$ & $4118 \mathrm{c}$ \\
\hline NS6060IPRO & $3224 \mathrm{~dB}$ & $3575 \mathrm{fB}$ & $1343 \mathrm{eD}$ & $1948 \mathrm{eC}$ & 4898bA & $2997 \mathrm{eB}$ & $2150 \mathrm{fC}$ & $2098 \mathrm{eC}$ & $2779 \mathrm{~h}$ \\
\hline NS6700IPRO & $4395 \mathrm{bA}$ & 4691dA & $4091 \mathrm{cA}$ & $3369 \mathrm{cB}$ & $4396 \mathrm{cA}$ & $4376 \mathrm{cA}$ & $4258 \mathrm{cA}$ & $4251 \mathrm{aA}$ & $4228 c$ \\
\hline NS6906IPRO & $3940 \mathrm{cC}$ & $6265 \mathrm{aA}$ & $4474 \mathrm{bB}$ & $3983 b \mathrm{~b}$ & $4279 \mathrm{cC}$ & $3968 \mathrm{cC}$ & $4945 b B$ & $3827 b C$ & $4460 \mathrm{~b}$ \\
\hline TMG2158PRO & $5231 \mathrm{aA}$ & $4975 \mathrm{cA}$ & $4513 b B$ & $2388 \mathrm{eD}$ & $4946 \mathrm{bA}$ & $4005 \mathrm{cC}$ & $4664 \mathrm{bB}$ & $2275 \mathrm{eD}$ & $4124 c$ \\
\hline
\end{tabular}


with the NS6906IPRO, in Corbélia, PR, however, it did not differ significantly from the BMX Potência RR, NS6823RR, NS 7300 IPRO, and NS 7209 IPRO in the same environment; this behavior was not repeated in the other sites. BMX Ativa RR showed the worse average performance in the set of study sites, with 2,284 $\mathrm{kg} \mathrm{ha}^{-1} \mathrm{GY}$.

The strongest, positive genetic effects were obtained for NA 5909 RG, M6410IPRO, NS 5959 IPRO, and NS6823RR, which had therefore the highest genetic values free of interaction $(\mu+\mathrm{g})$ (Table 5). The highest negative effects were obtained for the BMX Ativa RR, NS6060IPRO, and A 6411RG, with genetic values far below the average. The new estimated means suggest that the genotype ranking remained similar to that obtained by the comparison of the fixed-model means, and that changes occurred in genotypes with intermediate ranking. Similarly, the predicted genotypic $(\mu+\mathrm{g})$ values and the mean genotypic values $(\mu+\mathrm{g}+\mathrm{gem})$ showed the same classification between genotypes; this indicates that the recommendation - besides being the same - can be made by both parameters; this also makes it possible to recommend the cultivars for untested sites in the experimental network using $(\mu+\mathrm{g})$ values, as the genotypic performance is free of interactions in this case. A similar result was also reported by Borges et al. (2012).

The NA 5909 RG, NS6823RR, M6410IPRO, and M5917IPRO were the most stable cultivars and had the highest mean yield based on the HMGV method. BMX Ativa RR, NS6060IPRO, and A 6411RG were the most unstable and least productive cultivars. The genotypic stability analysis using that method is related to the dynamic concept of stability, associated with GY (Resende, 2004); thus, the lower is the standard deviation of the genotypic performance between sites, the higher is the HMGV. Therefore, selection by HMGV simultaneously leads to selection for both yield and stability (Resende \& Duarte, 2007).

NA 5909RG, NS6823RR, M6410IPRO, NS6767RR, M5917IPRO, and NS 5959 IPRO cultivars had the highest $\mathrm{RPGV}^{*} \mathrm{OM}$ values. Selection using $\mathrm{RPGV}^{*} \mathrm{OM}$ enables the identification of the most adapted genotypes by increasing the ability of each genotype to respond favorably to an improvement in the production environment. Furthermore, this parameter is associated with the mean yield, which enables the identification of both well-adapted and productive genotypes. This method can be compared with the one reported by Annicchiarico (1992), since it uses relative performance. However, these two methods differ for their measurement of adaptability, which is genotypically performed by the RPGV*OM and, phenotypically performed in the method of Annicchiarico (1992) (Carbonell et al., 2007).

NA 5909 RG, M6410IPRO, NS6823RR, and NS 5959 IPRO cultivars had the highest values, based on the HMRPGV*OM method, which indicates that they are simultaneously the most productive, stable, and adapted to the study sites. BMX Ativa RR, NS6060IPRO, and A 6411RG cultivars had the worst yield performances, adaptability, and stability. That method has the advantage of assessing the relative performance of genotypes in the genotypic context, unlike other widely used methods, as the methods by Lin \& Binns (1988) and Annichiarico (1992), which consider the values in the phenotypic context (Borges et al., 2010).

In the total set of cultivars, NA 5909 RG, NS 5959 IPRO, and M6410IPRO had the highest mean yields, based on the GGE biplot method (Figure 1). The classification is done in relation to the singlearrow line indicating that the farther to the right it is, the higher the genotype average will be. AS 3570IPRO, NS 6209, 6563RSF IPRO, and NA 5909 RG were the most stable cultivars because they showed a small projection in relation to the two-arrow line. However, these genotypes respond poorly to environmental changes. AS 3570IPRO cultivar failed to show both a high stability and mean yield, failing to meet the breeding objectives. However, NA 5909 RG cultivar had adequate values for both characteristics.

Among the early cultivars, BMX Energia RR and DMario 58i had the highest mean yields, and NS 4901 was the most stable cultivar. Among the mediumcycle cultivars, NA 5909 RG, NS 5959 IPRO, and M5917IPRO were the most productive genotypes, and 5958RSF IPRO the most stable ones. Among the late-cycle cultivars, M6410IPRO had the best yield performance associated with high stability. Similarly, the NS 6767 RR and NS6823RR cultivars were also productive and stable. The A 6411RG, NS 7237 IPRO, and NS 7338 IPRO showed high stability; however, 
they had the worst yield performances. Stability is measured biologically by the GGE biplot method, that is, the genotype has a consistent performance among all the environments, but fails to respond to environmental improvements (Jamshidmoghaddam \& Pourdad, 2013).

Table 5. Genetic effects $(\mathrm{g})$, predicted genotypic values $(\mathrm{u}+\mathrm{g})$, gain, new mean of the genotype, ranking of genotypes by the new mean $(\mathrm{u}+\mathrm{g}+\mathrm{gem})$, mean genotypic value in the environments, and methods of adaptability and stability, using mixed models.

\begin{tabular}{|c|c|c|c|c|c|c|c|c|c|}
\hline Cultivar & $\mathrm{g}$ & $\mathrm{u}+\mathrm{g}$ & Gain & New mean & Rank & $\mathrm{u}+\mathrm{g}+\mathrm{gem}$ & HMGV & $\begin{array}{l}\mathrm{RPGV} \\
* \mathrm{OM}\end{array}$ & $\begin{array}{l}\text { HMRPGV } \\
\text { *OM }\end{array}$ \\
\hline BMX Potência RR & 242 & 4260 & 424 & 4441 & 14 & 4300 & 4155 & 4300 & 4254 \\
\hline DMario $58 \mathrm{i}$ & -64 & 3953 & 247 & 4265 & 29 & 3942 & 3702 & 3904 & 3852 \\
\hline NK 7059 RR & 242 & 4259 & 412 & 4429 & 15 & 4299 & 4178 & 4317 & 4260 \\
\hline A 6411RG & -988 & 3029 & 57 & 4075 & 44 & 2867 & 2559 & 2866 & 2605 \\
\hline BMX Ativa RR & -1468 & 2550 & 0 & 4017 & 46 & 2308 & 2056 & 2291 & 2111 \\
\hline BMX Energia RR & 8 & 4025 & 295 & 4313 & 25 & 4027 & 3913 & 4042 & 3998 \\
\hline NA 5909 RG & 706 & 4723 & 706 & 4723 & 1 & 4839 & 4718 & 4855 & 4829 \\
\hline NS 4823 & -545 & 3472 & 81 & 4099 & 43 & 3382 & 3195 & 3363 & 3293 \\
\hline BMX Turbo RR & 258 & 4276 & 454 & 4472 & 12 & 4318 & 4059 & 4278 & 4219 \\
\hline NS 5858 & -198 & 3819 & 181 & 4198 & 35 & 3787 & 3631 & 3785 & 3736 \\
\hline NS 6262 & -136 & 3881 & 214 & 4231 & 32 & 3859 & 3630 & 3823 & 3773 \\
\hline SYN1059 RR & 189 & 4206 & 376 & 4394 & 18 & 4237 & 4073 & 4223 & 4203 \\
\hline NS 6767 RR & 484 & 4502 & 557 & 4574 & 6 & 4582 & 4497 & 4615 & 4572 \\
\hline TMG 7262RR & 119 & 4136 & 354 & 4371 & 20 & 4156 & 3795 & 4081 & 3992 \\
\hline NS 4901 & -206 & 3812 & 170 & 4187 & 36 & 3778 & 3582 & 3745 & 3716 \\
\hline NS 5258 & -39 & 3978 & 282 & 4300 & 26 & 3972 & 3780 & 3960 & 3908 \\
\hline NS 5290 & -118 & 3900 & 225 & 4243 & 31 & 3880 & 3634 & 3841 & 3782 \\
\hline NS 5401 RR & -378 & 3640 & 108 & 4126 & 41 & 3577 & 3445 & 3580 & 3533 \\
\hline NS 6209 & 98 & 4116 & 341 & 4359 & 21 & 4132 & 4028 & 4155 & 4104 \\
\hline NS6121RR & -153 & 3864 & 203 & 4220 & 33 & 3839 & 3701 & 3830 & 3800 \\
\hline NS6823RR & 531 & 4548 & 593 & 4610 & 4 & 4635 & 4572 & 4683 & 4634 \\
\hline M6210IPRO & 353 & 4370 & 505 & 4522 & 9 & 4428 & 4366 & 4473 & 4427 \\
\hline M6410IPRO & 582 & 4599 & 644 & 4661 & 2 & 4695 & 4529 & 4704 & 4646 \\
\hline 5958RSF IPRO & 243 & 4261 & 438 & 4455 & 13 & 4301 & 4179 & 4306 & 4279 \\
\hline 6458RSF IPRO & 212 & 4230 & 399 & 4417 & 15 & 4265 & 4178 & 4283 & 4266 \\
\hline 6563RSF IPRO & 475 & 4492 & 545 & 4562 & 7 & 4570 & 4460 & 4590 & 4555 \\
\hline AS 3570IPRO-(M 3570 IPRO) & -336 & 3681 & 133 & 4150 & 39 & 3626 & 3493 & 3632 & 3586 \\
\hline AS 3610IPRO & 334 & 4352 & 488 & 4505 & 10 & 4407 & 4332 & 4436 & 4412 \\
\hline M5917IPRO & 484 & 4502 & 571 & 4588 & 5 & 4582 & 4501 & 4612 & 4585 \\
\hline NS 5000 IPRO & -365 & 3652 & 121 & 4138 & 40 & 3592 & 3422 & 3585 & 3520 \\
\hline NS 5106 IPRO & -42 & 3975 & 270 & 4288 & 27 & 3968 & 3721 & 3932 & 3862 \\
\hline NS 5151 IPRO & -76 & 3941 & 237 & 4254 & 30 & 3928 & 3789 & 3918 & 3896 \\
\hline NS 5445 IPRO & -394 & 3624 & 96 & 4114 & 42 & 3559 & 3337 & 3522 & 3466 \\
\hline NS 5959 IPRO & 552 & 4570 & 613 & 4631 & 3 & 4661 & 4451 & 4639 & 4601 \\
\hline NS 6909 IPRO & -62 & 3955 & 259 & 4276 & 28 & 3945 & 3648 & 3895 & 3809 \\
\hline NS 7000 IPRO & 315 & 4333 & 472 & 4489 & 11 & 4385 & 4301 & 4436 & 4353 \\
\hline NS 7209 IPRO & 196 & 4213 & 387 & 4405 & 17 & 4246 & 4113 & 4328 & 4130 \\
\hline NS 7237 IPRO & -322 & 3695 & 145 & 4163 & 38 & 3642 & 3495 & 3681 & 3540 \\
\hline NS 7300 IPRO & 30 & 4047 & 307 & 4325 & 24 & 4052 & 3895 & 4074 & 3956 \\
\hline NS 7338 IPRO & -168 & 3850 & 192 & 4209 & 34 & 3822 & 3744 & 3858 & 3807 \\
\hline NS 5727 IPRO & -277 & 3740 & 158 & 4175 & 37 & 3694 & 3492 & 3676 & 3597 \\
\hline NS 6006 IPRO & 85 & 4103 & 319 & 4337 & 23 & 4117 & 3883 & 4087 & 4024 \\
\hline NS6060IPRO & -1048 & 2969 & 33 & 4050 & 45 & 2796 & 2473 & 2764 & 2546 \\
\hline NS6700IPRO & 179 & 4196 & 366 & 4383 & 19 & 4225 & 4187 & 4276 & 4243 \\
\hline NS6906IPRO & 375 & 4392 & 524 & 4541 & 8 & 4454 & 4356 & 4496 & 4416 \\
\hline TMG2158IPRO & 91 & 4108 & 330 & 4347 & 22 & 4123 & 3778 & 4059 & 3960 \\
\hline
\end{tabular}

HMGV, harmonic mean of the genotypic values; $\mathrm{RPGV}^{*} \mathrm{OM}$, relative performance of the predicted genotypic values multiplied by the overall mean of all environments; HMRPGV*OM, harmonic mean of the relative performance of the genotypic values multiplied by the overall mean of all environments. 
The ideal cultivar - the one closest to the center of the concentric circles - is based on high yield and stability criteria (Yan, 2015). Therefore, in the combined analysis, NA 5909 RG and M6410IPRO may be considered ideal cultivars (Figure 2). BMX Energia RR and DMario 58i stood out among all the early cultivars, and NA 5909 RG, which proved ideal, stood out among the medium-cycle cultivars. Among the late cultivars, M6410IPRO was the closest to the ideal cultivar. Identifying adapted and stable genotypes for a wide region enables breeders to use this source of germplasm towards developing
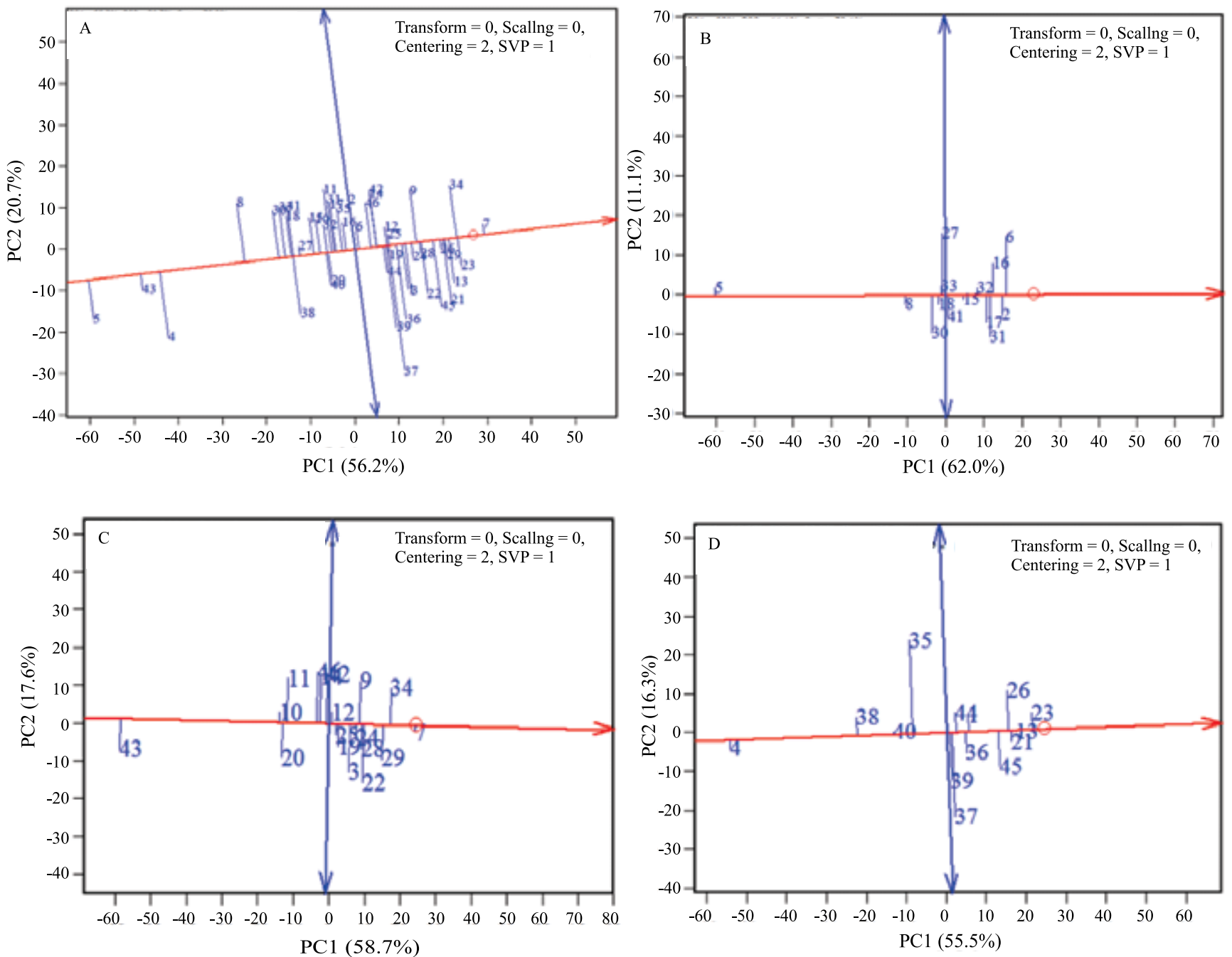

Figure 1. Mean and stability for the set of 46 soybean cultivars (A), and for the cultivar division in early (B), medium (C) and late cycles (D), evaluated in eight locations - seven of which in the state of Paraná (Cambé, Corbélia, Mamborê, Palotina, Realeza, São Jorge do Ivaí, and São Miguel do Iguaçu), and one in the state of São Paulo (Cândido Mota) -, in the 2014/2015 crop season. Cultivars: BMX Potência RR (1), DMario 58i (2), NK 7059 RR (3), A 6411RG (4), BMX Ativa RR (5), BMX Energia RR (6), NA 5909 RG (7), NS 4823 (8), BMX Turbo RR (9), NS 5858 (10), NS 6262 (11), SYN1059 RR (12), NS 6767 RR (13), TMG 7262RR (14), NS 4901 (15), NS 5258 (16), NS 5290 (17), NS 5401 RR (18), NS 6209 (19), NS6121RR (20), NS6823RR (21), M6210IPRO (22), M6410IPRO (23), 5958RSF IPRO (24), 6458RSF IPRO (25), 6563RSF IPRO (26), AS 3570IPRO (27), AS 3610IPRO (28), M5917IPRO (29), NS 5000 IPRO (30), NS 5106 IPRO (31), NS 5151 IPRO (32), NS 5445 IPRO (33), NS 5959 IPRO (34), NS 6909 IPRO (35), NS 7000 IPRO (36), NS 7209 IPRO (37), NS 7237 IPRO (38), NS 7300 IPRO (39), NS 7338 IPRO (40), NS 5727 IPRO (41), NS 6006 IPRO (42), NS6060IPRO (43), NS6700IPRO (44), NS6906IPRO (45), and TMG2158IPRO (46). PC, principal component. 
new cultivars for adaptation to a wide range of environments.

The methods to identify ideal genotypes via GGE, and stability via HMGV, coincided to show NA 5909 RG and M6410IPRO as superior cultivars. However, these two methods are not always coincident in the identification of adapted and stable genotypes. Yang et al. (2009) suggest that their simultaneous use is advantageous because these parameters consider the phenotype, when using GGE, and the genotype, when using mixed models. These methods also showed agreement regarding the cultivars with the worst performances, in which BMX Ativa RR, NS6060IPRO, and A 6411RG were the least stable and productive ones.
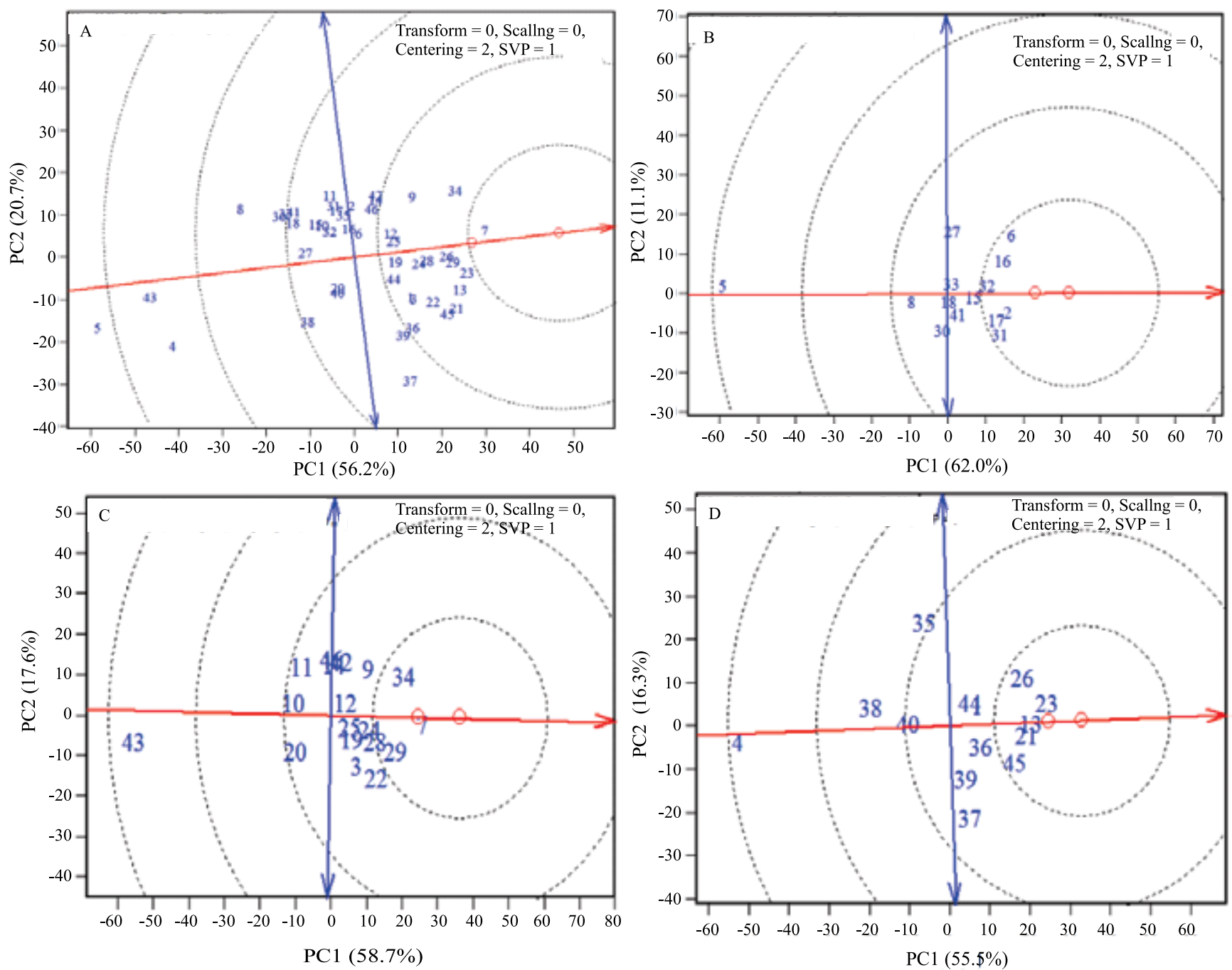

Figure 2. Ideal genotype of the set of 46 soybean cultivars (A), and for the cultivar divisions in early (B), medium (C) and late cycles (D), evaluated in eight locations - seven of which in the state of Paraná (Cambé, Corbélia, Mamborê, Palotina, Realeza, São Jorge do Ivaí, and São Miguel do Iguaçu), and one in the state of São Paulo (Cândido Mota) -, in the 2014/2015 crop season. Cultivars: BMX Potência RR (1), DMario 58i (2), NK 7059 RR (3), A 6411RG (4), BMX Ativa RR (5), BMX Energia RR (6), NA 5909 RG (7), NS 4823 (8), BMX Turbo RR (9), NS 5858 (10), NS 6262 (11), SYN1059 RR (12), NS 6767 RR (13), TMG 7262RR (14), NS 4901 (15), NS 5258 (16), NS 5290 (17), NS 5401 RR (18), NS 6209 (19), NS6121RR (20), NS6823RR (21), M6210IPRO (22), M6410IPRO (23), 5958RSF IPRO (24), 6458RSF IPRO (25), 6563RSF IPRO (26), AS 3570IPRO (27), AS 3610IPRO (28), M5917IPRO (29), NS 5000 IPRO (30), NS 5106 IPRO (31), NS 5151 IPRO (32), NS 5445 IPRO (33), NS 5959 IPRO (34), NS 6909 IPRO (35), NS 7000 IPRO (36), NS 7209 IPRO (37), NS 7237 IPRO (38), NS 7300 IPRO (39), NS 7338 IPRO (40), NS 5727 IPRO (41), NS 6006 IPRO (42), NS6060IPRO (43), NS6700IPRO (44), NS6906IPRO (45), and TMG2158IPRO (46). PC, principal component. 


\section{Conclusions}

1. NA 5909 RG, M6410IPRO, NS 5959 IPRO, NS6823RR, M5917IPRO, NS 6767 RR, and 6563RSF IPRO are the most productive cultivars in the study environments, and BMX Ativa RR shows the worst yield performance.

2. NA 5909 RG, NS6823RR, M6410IPRO, and NS 5959 IPRO show high yield, adaptability, and stability, and may be considered ideal cultivars for cultivation in the study sites.

3. There are modern soybean cultivars which are ideal for cultivation in the Brazilian soybean microregions of adaptation 102, 201, and 202.

\section{Acknowledgments}

To Conselho Nacional de Desenvolvimento Científico e Tecnológico ( $\mathrm{CNPq})$, for granting the overseas research and doctoral scholarship; and to Coordenação de Aperfeiçoamento de Pessoal de Nível Superior (Capes), for granting the masters and doctoral scholarships.

\section{References}

ANDRADE, A.C.B.; SILVA, A.J. da; FERRAUDO, A.S.; UNÊDA-TREVISOLI, S.H.; DI MAURO, A.O. Strategies for selecting soybean genotypes using mixed models and multivariate approach. African Journal of Agricultural Research, v.11, p.2331, 2016. DOI: 10.5897/AJAR2015.9715.

ANNICCHIARICO, P. Cultivar adaptation and recommendation from alfalfa trials in Northern Italy. Journal of Genetics and Breeding, v.46, p.269-278, 1992.

BORGES, V.; SOARES, A.A.; REIS, M.S.; RESENDE, M.D.V.; CORNÉLIO, V.M.O.; LEITE, N.A.; VIEIRA, A.R. Desempenho genotípico de linhagens de arroz de terras altas utilizando metodologia de modelos mistos. Bragantia, v.69, p.833-841, 2010. DOI: 10.1590/S0006-87052010000400008.

BORGES, V.; SOARES, A.A.; RESENDE, M.D.V. de.; REIS, M. de S.; CORNELIO, V.M. de O.; LEITE, N.A.; SOARES, P.C.; COSTA JÚNIOR, G.T. Value for cultivation and use of upland rice cultivars tested in multi-environments. Crop Breeding and Applied Biotechnology, v.12, p.25-33, 2012. DOI: 10.1590/S198470332012000100004.

BRANQUINHO, R.G.; DUARTE, J.B.; SOUZA, P.I.M. de; SILVA NETO, S.P. da; PACHECO, R.M. Estratificação ambiental e otimização de rede de ensaios de genótipos de soja no Cerrado. Pesquisa Agropecuária Brasileira, v.49, p.783-795, 2014. DOI: 10.1590/S0100-204X2014001000005.

CARBONELL, S.A.M.; CHIORATO, A.F.; RESENDE, M.D.V. de; DIAS, L.A. dos S.; BERALDO, A.L.A.; PERINA, E.F.
Estabilidade de cultivares e linhagens de feijoeiro em diferentes ambientes no Estado de São Paulo. Bragantia, v.66, p.193-201, 2007.

CONAB. Companhia Nacional de Abastecimento. Séries históricas. Available at: <http://www.conab.gov.br/conteudos. php? $\mathrm{a}=1252 \& \&$ Pagina_objcmsconteudos $=3>$. Accessed on: Sep. 12016.

COSTA, A.F.; LEAL, N.R.; VENTURA, J.A.; GONÇALVES, L.S.A.; AMARAL JÚNIOR, A.T. do; COSTA, H. Adaptability and stability of strawberry cultivars using a mixed model. Acta Scientiarum. Agronomy, v.37, p.435-440, 2015. DOI: 10.4025/ actasciagron.v37i4.18251.

CRUZ, C.D. GENES: a software package for analysis in experimental statistics and quantitative genetics. Acta Scientiarum. Agronomy, v.35, p.271-276, 2013. DOI: 10.4025/ actasciagron.v35i3.21251.

GOMEZ, G.M.; UNÊDA-TREVISOLI, S.H.; PINHEIRO, J.B.; DI MAURO, A.O. Adaptive and agronomic performances of soybean genotypes derived from different genealogies through the use of several analytical strategies. African Journal of Agricultural Research, v.9, 2146-2157, 2014. DOI: 10.5897/AJAR2014.8700.

JAMSHIDMOGHADDAM, M.; POURDAD, S.S. Genotype $\mathrm{x}$ environment interactions for seed yield in rainfed winter safflower (Carthamus tinctorius L.) multi-environment trials in Iran. Euphytica, v.190, p.357-369, 2013. DOI: 10.1007/s10681012-0776-z.

KASTER, M.; FARIAS, J.R.B. Regionalização dos testes de Valor de Cultivo e Uso e da indicação de cultivares de soja - terceira aproximação. Londrina: Embrapa Soja, 2012. 69p. (Embrapa Soja. Documentos, 330).

LIN, C.S.; BINNS, M.R. A superiority measure of cultivar performance for cultivar $\mathrm{x}$ location data. Canadian Journal of Plant Science, v.68, p.193-198, 1988. DOI: 10.4141/cjps88-018.

LOPES, M.S.; REYNOLDS, M.P.; MANES, Y.; SINGH, R.P.; CROSSA, J.; BRAUN, H.J. Genetic yield gains and changes in associated traits of CIMMYT spring bread wheat in a "historic" set representing 30 years of breeding. Crop Science, v.52, p.11231131, 2012. DOI: 10.2135/cropsci2011.09.0467.

OLIVEIRA, A.C.B. de; ROSA, A.P.S.A. da (Ed.). Indicações técnicas para a cultura da soja no Rio Grande do Sul e em Santa Catarina, safras 2014/2015 e 2015/2016. Pelotas: Embrapa Clima Temperado, 2014. (Embrapa Clima Temperado. Documentos, 382). XL Reunião de Pesquisa de Soja da Região Sul.

PEIXOUTO, L.S.; NUNES, J.A.R.; FURTADO, D.F. Factor analysis applied to the G+ GE matrix via REML/BLUP for multienvironment data. Crop Breeding and Applied Biotechnology, v.16, p.1-6, 2016. DOI: 10.1590/1984-70332016v16n1a1.

PINHEIRO, L.C. de M.; GOD, P.I.V.G.; FARIA, V.R.; OLIVEIRA, A.G.; HASUI, A.A.; PINTO, E.H.G.; ARRUDA, K.M.A.; PIOVESAN, N.D.; MOREIRA, M.A. Parentesco na seleção para produtividade e teores de óleo e proteína em soja via modelos mistos. Pesquisa Agropecuária Brasileira, v.48, p.1246-1253, 2013. DOI: 10.1590/S0100-204X2013000900008. 
QIN, J.; XU, R.; LI, H.; YANG, C.; LIU, D.; LIU, Z.; ZHANG, L.; LU, W.; FRETT, T.; CHEN, P.; ZHANG, M.; QIU, L. Evaluation of productivity and stability of elite summer soybean cultivars in multi-environment trials. Euphytica, v.206, p.759-773, 2015. DOI: $10.1007 / \mathrm{s} 10681-015-1513-1$.

RESENDE, M.D.V. de. Métodos estatísticos ótimos na análise de experimentos de campo. Colombo: Embrapa Florestas, 2004. 65p. (Embrapa Florestas. Documentos, 100).

RESENDE, M.D.V. de. Software Selegen - REML/BLUP. Colombo: Embrapa Florestas, 2002. 67p. (Embrapa Florestas. Documentos, 77).

RESENDE, M.D.V. de; DUARTE, J.B. Precisão e controle de qualidade em experimentos de avaliação de cultivares. Pesquisa Agropecuária Tropical, v.37, p.182-194, 2007.

ROCHA, F. da; VIEIRA, C.C.; FERREIRA, M.C.; OLIVEIRA, K.C. de; MOREIRA, F.F.; PINHEIRO, J.B. Selection of soybean lines exhibiting resistance to stink bug complex in distinct environments. Food and Energy Security, v.4, p.133-143, 2015. DOI: $10.1002 /$ fes3.57.

ROSADO, A.M.; ROSADO, T.B.; ALVES, A.A.; LAVIOLA, B.G.; BHERING, L.L. Seleção simultânea de clones de eucalipto de acordo com produtividade, estabilidade e adaptabilidade. Pesquisa Agropecuária Brasileira, v.47, p.964-971, 2012. DOI: 10.1590/S0100-204X2012000700013.

SPINELLI, V.M.; DIAS, L.A.S.; ROCHA, R.B.; RESENDE, M.D.V. Estimates of genetic parameters with selection within and between half-sib families of Jatropha curcas L. Industrial Crops and Products, v.69, p.355-361, 2015. DOI: 10.1016/j. indcrop.2015.02.024.

YAN, W. GGEbiplot-a Windows application for graphical analysis of multi-environment trial data and other types of twoway data. Agronomy Journal, v.93, p.1111-1118, 2001. DOI: 10.2134/agronj2001.9351111x.

YAN, W. Mega-environment analysis and test location evaluation based on unbalanced multiyear data. Crop Science, v.55, p.113122, 2015. DOI: 10.2135/cropsci2014.03.0203.

YANG, R.-C.; CROSSA, J.; CORNELIUS, P.L.; BURGUEÑO, J. Biplot analysis of genotype $\times$ environment interaction: proceed with caution. Crop Science, v.49, p.1564-1576, 2009. DOI: 10.2135/cropsci2008.11.0665.

Received on May 19, 2016 and accepted on September 29, 2016 